\title{
Circling the Blood in the Water: The Difficulties in Endangered Species Protections for the Great White Shark
}

\author{
Derek Julio \\ S.J. Quinney College of Law, Salt Lake City, USA \\ Email: Derek.julio@law.utah.edu
}

Received 3 June 2014; revised 11 July 2014; accepted 30 July 2014

Copyright (C) 2014 by author and Scientific Research Publishing Inc. This work is licensed under the Creative Commons Attribution International License (CC BY). http://creativecommons.org/licenses/by/4.0/ (c) () Open Access

\section{Abstract}

The purpose of legislation like the Endangered Species Act is to provide a means to conserve the ecosystems of endangered and threatened species, but not all species that may appear to need conservation are granted protection. An estimated $\mathbf{1 0 0}$ million sharks are killed each year largely due to exploitation, yet few shark species are ever granted protection under state or federal endangered species acts. The Northeastern Pacific population of the Great White Shark is no exception. Despite the numerous threats facing the white shark, NOAA denied a petition to list it as an endangered or threatened species under the federal Endangered Species Act. In light of the pending California decision to list the white shark under its state endangered species act, this paper considers whether or not such extreme protections are necessary. This paper first discusses the threats facing the white shark, the listing processes of both the federal and the California endangered species acts, and NOAA's 12-month negative finding. Finally, this paper concludes that endangered species protections are not warranted in the case of the Northeastern Pacific white shark because of prior government intervention and conservation efforts already in place.

\section{Keywords}

Endangered Species Act, ESA, CESA, California Endangered Species Act, Great White Shark

\section{Introduction}

There are over 400 described shark species roaming the Earth's oceans today, and new species are still being discovered [1]. Sharks are older than the dinosaurs [1]. Fossil records indicate that ancestors of modern sharks inhabited the oceans over 400 million years ago, with the modern shark emerging around 100 million years ago 
[2]. Millions of years of evolution have allowed sharks to develop unique and remarkable capabilities in finding and catching prey, making them extraordinarily efficient predators that have been able to survive all five major extinction periods [2]. Nevertheless, despite the evolutionary advantage sharks have enjoyed for millions of years, they are now facing an ever-growing evolutionary challenge: humans.

The human-made threats facing sharks are many. In addition to factors that challenge all marine life, such as pollution and destruction of habitat [3], sharks face unique threats. Sharks are often the focus of negative media attention because of their sometimes-lethal interactions with humans [4]. In addition to the media's exaggeration of sharks' threat to human safety, some species are targeted as a source for sports fishing, and their jaws are often collected as trophies [5]. Furthermore, an estimated 100 million sharks are hunted and killed each year for their fins because of the demand for shark fin soup [6]. Hence, the importance of adequate conservation of these magnificent predators cannot be overlooked.

Sharks are apex predators, having very few natural predators of their own, and reside at the top of their food chains [7]. As apex predators, sharks play a vital in role balancing the oceanic ecosystem and maintaining populations of other marine species [7]. Despite their place at the top of various oceanic food webs, however, many shark species have become exceptionally vulnerable to overfishing. According to some studies, an estimated 100 million sharks are killed each year as a result of exploitation [6]. This mortality rate exceeds the average rebound rates for many shark populations [6] and may be leading to drastic population declines of certain species [6]. In the interest of protecting oceanic ecosystems, government action may required to implement protective measures to prevent further decline in shark species, to rebuild populations, and to restore oceanic ecosystems with a functional apex predator [6].

The Great White shark (Carcharodon carcharias), in particular, is vulnerable to human-induced threats because of its naturally late maturity and low reproduction rates [7]. The white shark's longevity is estimated to be between 23 - 60 years [7]. It is further estimated that female white sharks mature at $12-18$ years $(4-5 \mathrm{~m}$ total length), and males mature at 8 - 10 years (3.5 - $4.1 \mathrm{~m}$ total length) [7]. Females typically give birth at two- or three-year intervals to average litters of seven pups after an estimated 12 - 18 month gestation period [7]. Hence, overexploitation from the global shark finning trade, trophy hunting, paranoia-inducing media, and adventure tourism could have lasting effects on white shark populations [8]. Some studies estimate that, within the last fifty years, there has been a reported decline of between $60 \%$ - 95\% in global white shark numbers [9]. Nevertheless, despite the growing concern with regard to white shark populations, attempts to list the species under the federal Endangered Species Act (ESA) [10] have so far failed [11].

This comment considers the threats facing the Northeastern Population (NEP) of the white shark and the difficulties in providing state and federal endangered species protection to that population. In Part I, this comment provides the background information regarding the Great White shark and the threats facing it. Part II, in turn, it discusses the federal and California endangered species protections and examines the petitions to list the NEP shark as endangered or threatened. Finally, this comment focuses on the pending California decision and considers whether the endangered species protections are appropriate in the case of the NEP white shark.

\section{Background on the White Shark and the Threats Facing It}

\subsection{Threats Facing Global White Shark Populations}

Great White sharks (Carcharodon carcharias)—commonly known as white sharks, white pointers, blue pointers, or white death-are the largest known predatory fish in the ocean [12]. The species is known to primarily live in coastal regions, but it also roams the open ocean [13]. White sharks are most commonly observed in the inshore continental waters of the northeastern Pacific, the western north Atlantic, Mediterranean Sea, southern Africa, and southern and western Australia [13]. Reaching lengths of over 6.1 meters (approximately 20 feet), weighing up to 2268 kilograms (5000 pounds), and having countless rows of sharp, serrated teeth; it is no wonder that white sharks have been referred to as one of the most frightening animals on earth [14]. Indeed, the mere notion that this massive predatory fish roams coastal waters strikes fear into the hearts of beachgoers around the world [15].

Horror movies have perpetuated the fear of white sharks [16], and negative media attention has vilified and ultimately condemned them [4]. The best-selling novel and blockbuster film, Jaws, featured a giant Great White shark massacring the swimmers and boaters of the small island town of Amity Island [17]. Both the novel and the film depict the massive shark as a vengeful predator and a bloodthirsty, indiscriminate man-eater [17]. The 
film struck a horrific chord with moviegoers across the nation, leading to a reported decline in beach attendance from coast to coast [18]. As beachgoers fled the shores, shark trophy hunters took to the water in increasing numbers, all hoping to hunt and kill these giant, man-eating sharks [16]. Dozens of shark fishing tournaments contributed to a decline in white shark populations over the next three decades [16]. Since the release of Jaws, nearly fifty horror movies featuring killer sharks have been released, including 12 Days of Terror, Deep Blue Sea, Open Water, Sharktopus, and Sharknado [19].

Negative media attention focusing on the white shark and its sometimes-lethal interactions with humans has also exacerbated the widespread fear of sharks [4]. Indeed, sensationalist coverage of shark attacks can leave lasting impressions on the public. For example, news coverage of a series of shark attacks in the United States in 2001, deemed "The Summer of the Shark," ranked as the third "most important" news story in terms of absolute minutes on three major broadcast television networks [20]. Like the movie Jaws, the media attention focusing on fatal shark attacks portrays white sharks as indiscriminate man-eaters, rather than an apex predator necessary to a healthy ecosystem. Such media portrayal of sharks contributes to the public's fears of, and ill feelings towards, white sharks and drives the sentiment that "the only good shark is a dead shark. [21]" Such ill public opinion often creates a hurdle to shark conservation [4] [22]. The white shark is perceived as a monster, not a fish that deserves protection. As a result, the white shark is often a scapegoat that is targeted, hunted, and slaughtered in retaliation for fatal shark bite incidents [23].

Recent events in Western Australia exemplify the effect that these media "feeding frenzies" can have on shark populations and conservation efforts. In 2013, a series of four high-profile shark attacks led to a governmentsponsored culling hunt for white sharks [23]. This shark-killing policy allowed the use of government-monitored drum lines to catch and subsequently shoot white sharks or other large shark species [24]. The shark killing continues despite global opposition from scientist and conservationists [25] and despite the fact that Australia actually suffered a below-average number of attacks during 2013 [26].

White sharks are not the indiscriminate killers that the media portrays them to be. According to the International Shark Attack File, there were only ten fatalities worldwide that resulted from unprovoked shark attacks in 2013 [26]. The global average over the past decade is only six shark-related fatalities per year [26]. Fatal attacks by white sharks are even rarer. Between 1916 and 2001, only ninety-eight attacks in which white sharks were implicated were recorded [26]. Of those attacks, only nine were fatal [26]. Worldwide, there have been 263 unprovoked attacks involving white sharks over the past one hundred years, with only sixty-nine of those attacks being fatal [27]. Despite media focus on the danger white sharks pose to humans, a person is much more likely to be killed by lighting, snakes, or even vending machines [28] than by sharks.

In addition to negative media attention and trophy hunting, the white shark is also vulnerable to overexploitation. For hundreds of years, sharks have been hunted for their fins, oil, and teeth, all of which have contributed to severe declines of shark populations in recent decades [22]. The global shark fin trade further adds to the white shark's vulnerability [29]. Shark finning is a gruesome process wherein the fins are removed from the living shark with a hot blade [30]. The shark, which has little to no commercial value, is then discarded into the ocean to die a slow, lingering death from blood loss, drowning, or starvation [29].

The global shark fin trade claims countless numbers of sharks each year in order to keep up with the demand of shark fin soup [30]. Shark fin soup is a delicacy in some cultures and has been the highlight of corporate banquets, weddings, and other cultural celebrations for centuries [30]. Consumption of shark fins has steeply increased over the past thirty years and, as the demand continues to rise, so does the value of shark fins [31]. Fins sell for as much as $\$ 1100$ per kilogram (\$500 per pound), making big sharks worth thousands of dollars [32]. A single whale shark fin, for example, can sell for upwards of \$50,000 USD [32]. Hence, the white shark is under a constant threat of being finned because of its size and rarity.

All of these threats negatively affect the white shark, and continued population declines could have farreaching ramifications [33]. While it may be difficult to determine the extent of the effect a continued decline in white shark populations would have on the various marine ecosystems, it is best not to underestimate the importance of the role of apex predators [34]. White sharks maintain and limit seal and lion populations in California, and their removal could upset the balance of the Pacific Ocean's ecosystem [35]. For example, a similar decrease in white shark populations on the east coast of the United States resulted in higher populations of medium-sized predators, like the cownose ray, and decreased populations of bivalves, such as scallops [36].

The National Oceanic and Atmospheric Administration (NOAA) has previously acknowledged the importance of preserving white shark populations [37], as have international organizations such as the International 
Union for Conservation of Nature (IUCN), which categorized the global population of white shark as vulnerable on the IUCN Red List in 1996, 2000, and 2009 [12]. A species is categorized as vulnerable if the species is considered to be facing a high risk of extinction in the wild [38]. Both NOAA and the IUCN recognize that shark biology makes them highly susceptible to the threats of fishing and other human activities [12] [37]. Thus, both entities recognize that the white shark may require some level of government protection to prevent declining populations. Nevertheless, notwithstanding the growing concern over the threats facing white sharks, NOAA denied listing the NEP white shark population as threatened or endangered under the federal ESA [11].

\subsection{The Northeastern Pacific Great White Shark}

The NEP population is one of at least three white shark populations that are separated by migration routes and genetics, which primarily lives in the northeastern region of the Pacific Ocean near North America [39]. Information relating to the life history, growth and reproduction of the NEP white shark is limited, but the best available information indicates that Young-of-the-Year (YOY) white sharks, those that are in their first year of life, typically range anywhere from 1.2 - 1.75 meters in total length. Juvenile sharks range from 1.75 to 3.0 meters in total length [40]. Sub-adult white sharks range from 3.0 meters in total length to about 3.6 to 3.8 meters, the estimated size in which males mature [40].

Genetic sampling shows that the NEP white shark is reproductively isolated from the white sharks of the southwestern Pacific, despite the potential for the two populations to interbreed [39]. Genetic comparisons of NEP white sharks with specimens from Japan, Australia and South Africa reveal that the NEP population does not share any haplotypes with populations of any other area [11]. Haplotypes are "specific genetic sequences that are inherited" from the maternal parents [11]. The fact that genetic comparisons have not observed any shared haplotypes between samples from different regions strongly indicates the NEP population is genetically distinct and reproductively isolated from other populations [41].

In addition, NEP white sharks demonstrate consistent focus in the North American coastal and shelf waters [42] and are considered demographically isolated from the other populations in Australia, New Zealand, and South Africa. Tagging and satellite surveillance indicate a highly predictable seasonal distribution and a structured migratory cycle of NEP sharks that focus on three core areas: the North American shelf waters, the offshore waters of the Hawaiian archipelago, and the offshore white shark "Café," which is a remote, mid-ocean area to which white sharks travel and loiter [42]. YOY and juvenile sharks within the NEP are thought to prefer the shallow coastal waters, primarily in the Southern California Bight (SCB) and Baja California [43], which are likely sites of parturition [44]. Mature and sub-adult NEP white sharks show strong fidelity to sites in Central California, Guadalupe Island, and Mexico, near pinniped colonies, but are also observed far from shore at the Café [44].

\section{The Federal and California Endangered Species Protections}

The NEP population has a significant amount of habitat within the US exclusive economic zone (EEZ) [45] because of its seasonal distribution and structured migratory patterns throughout North American waters [46]. Therefore, the NEP population is largely subject to US control [46] [47]. NOAA's denial of ESA protections, and California's pending decision under the California Endangered Species Act (CESA) raise an interesting issue as to whether endangered species protections are the appropriate avenue for preserving and rebuilding the NEP population. Understanding and analyzing a species' listing eligibility requires an analysis of the complicated framework and statutory provisions of both the federal ESA and the CESA.

\subsection{Federal Endangered Species Act}

A species may qualify for protection under the ESA if it is threatened or endangered because any of the following factors: "a) the present or threatened destruction, modification, or curtailment of its habitat or range; b) overutilization for commercial, recreational, scientific, or educational purposes; c) disease or predation; d) the inadequacy of existing regulatory mechanisms; or e) other natural or manmade factors affecting its continued existence." [48]. An "endangered" species is defined as "any species that is in danger of extinction throughout all or a significant portion of its range." [48]. A "threatened" species is defined as any species, which is likely to become endangered within the foreseeable future throughout all or a significant portion of its range” [49]. A 
“species” may also include "any subspecies of fish ... and any distinct population segment of any species of vertebrate fish” [49].

The National Marine Fisheries Service (NMFS) and US Fish and Wildlife Service (USFWS) jointly published a policy clarifying the phrase "distinct population segment" and describing a three-part analysis for determining the status of a distinct population segment (DPS) [50]. The analysis includes: 1) the discreteness of the population segment in relation to the remainder of the species to which it belongs; 2) the significance of the population segment to its species; and 3) its conservation status in relation to the ESA's standards for listing [50]. If the agency determines that a population segment of vertebrate fish of wildlife is both discrete and significant, and therefore distinct, the agency will then evaluate the conservation status of the DPS under the ESA as though it were a an independent species eligible for listing [11].

NOAA concluded in its twelve-month finding that the NEP white shark constitutes a DPS under the ESA because it is discrete in relation to other white shark populations, and because it is significant to the global taxon [11]. First, the NEP's site fidelity, predictable seasonal distribution, and structured migratory cycle in the northeastern Pacific Ocean indicate that it is demographically separate from other white shark populations [11]. In addition, the lack of shared haplotypes indicates that the NEP white shark is reproductively isolated, and genetically separate from other populations in the southwest Pacific Ocean [11]. NOAA concluded that these genetic and demographic differences are sufficient to meet the discreteness requirement under the ESA [11]. NOAA also concluded that the NEP population is significant to the global population because 1) genetic evidence indicates that it is markedly different from other populations; and 2) the NEP occupies approximately half of the Pacific Ocean, and the "loss of the population would result in a significant gap in the range of the global taxon." [11]

The ESA offers a listed species protections in the form of critical habitat designation and take prohibitions [51]. The designated critical habitat protection under Section 4 of the ESA requires the identification and protection of all lands, water and air necessary to recover a threatened or endangered species [51]. When a species is listed as threatened or endangered, NMFS or USFWS designates critical habitat for the species as long as it is prudent to do so and as long as the critical habitat is determinable [51].

The ESA also provides a listed species with take prohibitions [51]. "Take” means to "harass, harm, pursue, hunt, shoot, wound, kill, trap, capture, or collect, or to attempt to engage in any such conduct [52].” Take prohibitions may apply differently depending on whether the species is endangered or threatened. If the species is listed as endangered, then take prohibitions automatically extend to it [51]. If a species is listed as threatened, then NMFS or the USFWS must issue protective measures in order to extend take prohibitions to the species [51].

\subsection{California Endangered Species Act}

A species may be listed as threatened or endangered under the CESA if "its continued existence is in serious danger or is threatened" by any one of the following factors: "1) Present or threatened modification or destruction of its habitat; 2) Overexploitation; 3) Predation; 4) Competition; 5) Disease; or 6) Other natural occurrences or human-related activities." [53]. Under the CESA, a species is "endangered" if is it "in serious danger of becoming extinct throughout all, or a significant portion, of its range.” [54]. A species is "threatened,” in turn, if it "is likely to become an endangered species in the foreseeable future in the absence of special protection and management efforts.” [55]. The statutes implementing CESA do not explicitly define the terms "species” and "subspecies” to include distinct population segments, as in the federal ESA [54]. However, California courts have held that species under the CESA include evolutionarily significant units and that the term "range" as used in Fish and Game Code, § 2062, refers to a species’ California range only [56]. Thus an evolutionary significant unit of a species' California range, such as that of the NEP white shark, may be entitled to protection under the CESA.

The CESA also offers a listed species protections in the form of critical habitat designation and take prohibitions. Section 2080 of the California Fish and Game Code prohibits the taking of any endangered or threatened species except for scientific or educational purposes and incidental takings [57]. "Take” is defined in Section 86 to mean "hunt, pursue, catch, capture, or kill, or attempt to hunt, pursue, catch, capture, or kill.” [58]. Under the CESA, the California Department of Wildlife (CDWF) may authorize, and issue permits to, individuals, universities, and scientific or educational institutions to import, export, take, or possess any endangered, threatened, or 
candidate species for scientific, educational, or management purposes [58]. The CESA allows for incidental takings in the course of otherwise lawful development projects, although it also encourages the avoidance potential impacts to endangered and threatened species by developing appropriate mitigation planning [58]. Section 2052 of the California Fish and Game Code permits the state legislature to acquire lands for the purpose of conserving, protecting, restoring, an endangered or threatened species and its habitat [59].

\section{Petitions to List the White Shark as Threatened or Endangered}

\subsection{The Two Petitions to Protect the Northeastern Pacific White Shark}

On June 25, 2012, NOAA received a petition from Wild Earth Guardians to list the NEP white shark as threatened or endangered under the ESA [60]. A second petition was jointly filed by Oceana Center for Biological Diversity and Shark Stewards on August 13, 2012 [60].

During its initial 90-day evaluation of the petition, as required under the ESA [60], NOAA relied on the scientific data that the petitioners provided to analyze the factors affecting the ability of the NEP white shark to survive and reproduce [60]. The petitions argued that the NEP white shark is especially vulnerable to human-caused threats because they are slow growing, late-maturing fish with a small number of offspring per reproductive cycle and a small adult population [61]. The petitioners also argued that critical habitat designations were necessary to preserve the NEP population because the nursery for juvenile white sharks is believed to be within the California Current and pupping likely occurs nearby [61].

The petitions described a number of factors that are negatively affecting the NEP white shark population, such as habitat degradation as a result of increasing human activity; continued incidental catching; disease caused by ocean contaminants such as mercury; the inadequacy of existing regulations; and other human-made factors such as negative media attention and bioaccumulation of contaminants [61]. All of these factors, according to the petitions, may be affecting the survival and recovery of the NEP white shark population [61].

These petitions initiated the ESA's required review process, which utilizes a two-step process in listing a species as threatened or endangered. First, NMFS conducts an initial 90-day review to determine whether the petition provides sufficient information to indicate that the petitioned action may be warranted [62]. If the petition does not present substantial information, NMFS will publish a negative 90-day finding denying the petition [62]. If the petition does present substantial information, NMFS publishes a positive 90-day finding and lists the species as a candidate under the ESA [62]. NMFS then conducts a thorough status review of the species based on the best available scientific information [62]. If NMFS determines that the listing is not warranted, a negative 12-month finding is published [62]. If listing is warranted, a positive 12-month finding is published within one year of the date of the petition, proposing to list the species as threatened or endangered [62].

On August 20, 2012, the California Fish and Game Commission (Commission) also received a petition filed jointly by Oceana Center for Biological Diversity and Shark Stewards to list the NEP population as threatened or endangered under CESA [63]. The CESA also requires a two-step evaluation process similar to the federal ESA. First, the Commission conducts a 90-day review to determine whether the petition provides sufficient information to indicate that the petitioned action may be warranted [64]. The Commission's 90-day report includes an evaluation of whether or not the petition provides sufficient scientific information regarding population trend, range, distribution, abundance, life history, kind of habitat necessary for survival, factors affecting the ability to survive and reproduce, degree and immediacy of threat, impact of existing management efforts, suggestions or future management, availability and sources of information, and a detailed distribution map [65]. If the petition is accepted and the species becomes a candidate species, Department of Fish and Game (Department) commences a status review of the species before publishing its 12-month finding [65].

\subsection{NOAA's Listing Denial}

NOAA published a positive 90-day finding on September 28, 2012, establishing the NEP white shark as a candidate species [60]. NOAA then formed a biological review team (BRT) of federal scientists to conduct a comprehensive status review of the NEP white shark [11]. After conducting its status review of the NEP population, NOAA published its negative 12-month finding on July 3, 2013 [11]. NOAA concluded that the available information suggested a stable or increasing NEP population that is at a low risk of overall extinction; as a result, the NEP white shark population's status did not warrant listing as threatened or endangered [11]. 
The 12-month finding provided a number of justifications for NOAA's decision not to list the white shark for protection. First, the BRT noted that insufficient information regarding the population size, offshore feeding habits, and reproduction of NEP white sharks prevented adequate evaluation of certain listing factors [11]. For example, because of uncertainty regarding the effect that contaminants have on a shark's health and the lack of specific information regarding the NEP's offshore foraging habits, the BRT could not adequately evaluate the potential risks of contaminants and debris in the NEP's habitat [11]. In addition, a lack of scientific information as to how parasites or concentrations of mercury found in sharks affect individuals, or populations, prevented the BRT from concluding that disease poses any high-level threat [11]. Furthermore, the BRT lacked sufficient information to find that either the threats of bioaccumulation of contaminants or competition with other species were factors affecting the NEP's continued existence [11].

Finally, the BRT concluded that, although information on population is uncertain, if the NEP population presently has at least 125 - 200 females, it would take 60 - 100 years for the population to decline to near extinction [11]. Based on population estimates provided by petitioners, the current adult population of white sharks in waters off central California is 219, with approximately 438 adult and sub-adult individuals in the entire northeastern Pacific Ocean [49]. Thus the NEP white shark is not likely in danger of extinction, or likely to become so within the foreseeable future.

NOAA concluded that the trends in abundance of the NEP shark population are consistent with a stable or increasing population [11]. Furthermore, NOAA found that the "threats to habitat destruction or modification, disease and predation, or other natural and man-made factors are not considered significant and are not contributing to increasing the extinction risk” of the NEP population [11].

\subsection{California’s Pending Determination}

On January 7, 2013, the California Fish and Game Commission published its positive 90-day finding and determined that there was sufficient information to indicate that the petitioned action may be warranted and listed the NEP as a candidate species [66]. The Commission initiated a status review of the NEP population; however, the 12-month finding has yet to be published [66].

Upon the publishing of its 90-day evaluation, the Commission agreed with the petitioners that the life history of the NEP white shark makes the species naturally low in abundance [66]. The Commission further agreed that white sharks are vulnerable to incidental fishing and habitat loss [66]. However, the Commission noted that the population status of the NEP white shark is largely unknown because white shark populations are so difficult to track and measure [66].

The lack of scientific data to demonstrate an actual decline in white shark populations is a significant hurdle to conservation of the NEP [11] [66]. Adding to the difficulty in determining population trends is the lack of information regarding historical populations [12]. The petitions submitted under both the federal ESA and CESA relied heavily on population estimates that suggest that the adult population of white sharks in waters off central California is 219, with approximately 438 adult and sub-adult individuals existing in the entire northeastern Pacific Ocean [47]. Not all shark experts, however, agree with those estimates [67].

Leading white shark expert Michael Domeier, whose work is cited throughout the petitions, criticized these estimates, stating that, "the population estimate was based upon several faulty assumptions and therefore this estimate is not valid" [67]. Noting the potential problems in trying to determine the population status of the NEP white shark, Domeier indicated that white shark populations are likely to be significantly higher than the previous estimates suggest [67]. Furthermore, while NOAA's BRT study did not provide any concrete estimates of the white shark population size, it concluded that the population is likely stable or increasing [11].

The California Fish and Game Commission also noted that the available information might actually indicate an increasing NEP population as a result of increased fishery restrictions [68]. The Commission recognized the need for further research, but it ultimately concluded that there was sufficient scientific information to indicate that the petitioned action may be warranted and listed the NEP as a candidate species [66].

As the Commission conducts its 12-month review and evaluates the listing factors, it is likely that it will face similar issues as NOAA did regarding insufficient information about the NEP white shark's biology and life habits. The Commission indicated that the lack of adequate information regarding the NEP white shark's life history and biology limit the Commission's ability to assess some of the threats alleged in the petitions [66]. Further studies conducted to as to the offshore feeding habits and the effect of pollution and disease during the 
12-month review period will not likely be any more conclusive than those conducted by NOAA because of the naturally low abundance of white sharks, the difficulty in tracking and measuring populations, and current protections that limit takings of white sharks for scientific purposes [66]. Despite the growing efforts and advances in understanding the age, growth, and reproductive biology of white sharks, there are still large gaps in information regarding their basic life history [66]. As a result, the white shark will continue to face difficulties in securing protection under the CESA.

\section{The Appropriateness of Endangered Species Protection}

The lack of sufficient scientific data regarding the white shark's population size, offshore feeding habits, and reproduction make evaluation of the NEP white shark's status difficult. This lack of information is a hurdle in white shark conservation efforts. Nevertheless, listing the white shark for protection under the CESA or ESA might not be the appropriate avenue for adequate conservation. A number of white shark-specific state and federal regulations have already been enacted that address many of the threats facing the NEP population of white sharks more adequately than endangered species protections could do.

\subsection{Existing Regulatory Mechanisms}

Both the Commission's 90-day evaluation and NOAA's 12-month finding indicate that the most current, foreseeable, and identifiable threat to the NEP white shark is mortality rates caused by overutilization and overexploitation for commercial, recreational, scientific or educational purposes [66]. These threats include fisheryrelated mortality from gillnet fisheries, recreational fisheries, ecotourism activities, and state-permitted scientific research [66]. Despite these threats, however, evidence suggests that regulations reducing gill net fishing and shark harvesting may be responsible for the stable and increasing NEP population [66]. Indeed, a number of protective efforts to reduce impacts on the NEP white shark, at the state, federal and international levels have been in place since the early 1990s.

\subsubsection{California State Regulations}

California has already implemented a number of regulations that prohibit the taking of white sharks. In 1994, the California Legislature added Sections 5517 and 8599 to the State Fish and Game Code [69]. Section 5517 makes the taking of any white shark unlawful except by special permit [69]. Section 8599 prohibits the taking of any white shark for commercial purposes except by special permit for scientific or educational purposes, but it allows the incidental taking of white sharks by commercial gillnet or round haul fishing operations [69].

In addition, several gillnet regulations have been in place in California waters since the 1980s, and these regulations may also have a positive impact on white shark populations [69]. In 1982, regulations were enacted that set seasonal gillnet closures [69]. Regulations enacted in 1986 eliminated thresher shark drift gill net fisheries within 12 nautical miles of shore north of Point Arguello and in areas around the Farallon Islands [69]. In 1994, California enacted the near shore gillnet ban in the Marine Reserved Protection Zone (MRPZ) [69]. The MRPZ ban prohibited gill net use within three nautical miles of the mainland shore south of Point Arguello [69].

Regulations of both offshore and near shore gillnet fisheries resulted in an overall decrease in gillnet fishing since the mid-1990s [66]. After the decrease in gillnet use, the number of incidental catch rates of YOY and juvenile white sharks have increased in southern California [70]. In addition, there has also been a documented increase in white shark bite mortality on sea otters [70]. This increase in white shark interactions suggests that the population of YOY and juvenile sharks may be increasing because of reduced near shore gill net fishing in Southern California and because of white shark protections already in place [70]. Indeed, there has been documented recovery of other large near shore fish populations as a result of gillnet bans [71]. If gillnet restrictions are indeed contributing to the protection of YOY and juvenile white sharks in southern California, where white shark nurseries are believed to be, then such restrictions might already be addressing some of the issues regarding habitat protections that would be afforded the NEP white shark under the CESA.

\subsubsection{US Federal Regulations}

A number of federal regulations have also been implemented specifically to prohibit commercial and recreational fishing of white sharks, to limit bycatch, and to prohibit the practice of shark finning [72]. These federal protections include the NOAA's West Coast Highly Migratory Species Fishery Management Plan (HMS FMP) [72], 
the Shark Finning Prohibition Act of 2000 [73], and the Shark Conservation Act of 2010 [74], and white-shark specific regulations in the west coast National Marine Sanctuaries [75].

The Magnus-Stevens Fishery Conservation and Management Act (MSA) of 1976 [76] established the Pacific Fishery Management Council (PFMC) to regulate fisheries within the U.S EEZ off the coasts of Washington, Oregon and California [77]. PFMC adopted the HMS FMP in 2003, allowing the PFMC to actively manage certain highly migratory species of fish, including tuna, sharks, and swordfish [77]. In addition, the PFMC may also monitor and regulate other species, including great white sharks [78]. The HMS FMP labels the white shark as a protected species that must be released immediately if caught by vessels fishing within the EEZ [77]. This requirement also applies to vessels fishing on the high seas that land their fish in California, Oregon, or Washington [77].

The Shark Finning Prohibition Act of 2000 amended the MSA to prohibit the practice of shark finning by any person under U.S jurisdiction [79]. Specifically, the Shark Finning Prohibition Act prohibits the possession of shark fins aboard any vessel within the US EEZ and prohibits any vessel from landing shark fins without the corresponding carcass [79].

In 2011, President Obama signed the Shark Conservation Act into law to in an effort to further strengthen the prohibitions on shark finning under the MSA [79]. The Shark Conservation Act prohibits any vessel within the EEZ from having custody of, transferring, or landing shark fins unless they are naturally attached to the corresponding shark carcass [79].

Protection is also afforded to white sharks within the Gulf of the Farallones National Marine Sanctuary (GFNMS), an area of 1282 square miles off the northern and central California coast, just a few miles from San Francisco [79]. GFNMS regulations prohibit vessels from approaching within fifty meters of any white shark within the two-mile radius around the Farallon Islands-an important measure given that a dense population of white sharks regularly feed in this area [79]. In addition, the Monterey Bay National Marine Sanctuary (MBMNS) in central California prohibits vessels from attracting white sharks [79]. Both sanctuaries adopted these prohibitions to regulate adventure tourism activities that may have a negative impact on the NEP population [79].

Other federal regulations not enacted specifically to protect white sharks may nevertheless also aid in maintaining the NEP white shark population by reducing bycatch. Such regulations include gillnet use requirements under the Pacific Offshore Cetacean Take Reduction Plan (POCTRP) and the Pacific Leatherback Conservation Area (PLCA) [80]. POCTRP and PLCA were enacted to reduce serious injuries to and deaths of marine species incidental to the California thresher shark/swordfish drift gillnet fishery [80]. POCTRP requires the use of extenders on gillnets to avoid cetaceans swimming near the surface, while the PLCA sets time and place restrictions on gillnet use throughout the year [80]. Both POCTRP and PLCA might provide some protection to the NEP white shark population by restricting gillnet use in the SCB [80].

It is thought that YOY and juvenile white sharks in the NEP prefer the shallow coastal waters of the SCB [44]. Satellite tagging studies suggest that the time and place restrictions have resulted in the current gillnet fishing activity overlapping with less than a third of the habitat thought to be home to YOY and juvenile sharks [70]. Thus, the BRT theorized that restrictions on gillnet use in the SCB may provide some level of protection by reducing interactions between gillnets and white sharks in the NEP [80]. Logbook records indicate that bycatch of juvenile and YOY white sharks in large mesh drift gillnet fisheries has steadily declined since the 1980s [80]. Thus, these regulations, while not directed specifically at the NEP white shark, may be addressing the threats to young sharks that would otherwise require endangered species protections.

\subsubsection{International Regulations}

A number of international regulations have been enacted in the past fifteen years that may directly or indirectly provide protection for global white shark populations. Both Canada and Mexico have adopted conservation measures that offer protections to the NEP white shark population [80]. In addition, the global population of white sharks, including the NEP, has been assessed under the Convention on International Trade in Endangered Species (CITES) [9], the International Union for Conservation of Nature (IUCN) [12], and the Conservation of Migratory Species of Wild Animals (CMS) [81].

In 1999, the United Nations Food and Agriculture Organization (FAO) adopted the International Plan of Action for the Conservation and Management of Sharks (IPOA-Sharks) to ensure that shark populations were adequately conserved and managed [82]. IPOA-Sharks encourages member and non-member states of FAO to de- 
velop national plans of action that require monitoring of shark catches in fisheries, minimize incidental catches, and assess threats to shark populations [82]. The United States, Canada, and Mexico are among a number of nations that have adopted and implemented national plans of action under IPOA-Sharks [83].

In 2002, the global population of the white shark was listed in both Appendix I and II of the CMS in an effort to coordinate conservation measures among various nations [81]. Migratory species are listed under Appendix I if they are threatened with extinction [81]. Migratory species are listed under Appendix II are considered to need, or would significantly benefit from, international co-operation [81]. CMS supports protection and conservation of listed species through legally binding treaties and non-legally binding Memoranda of Understanding [84]. The US, Mexico and Canada are not parties to CMS, but the US is a signatory to a $2010 \mathrm{MOU}$ that encourages signatories to adopt measures to protect white sharks [85].

In 2004, the global population of white sharks was listed under Appendix II of the CITES [7]. Appendix II includes species that may not necessarily be threatened with extinction, but may become so without international trade regulation [86]. Under CITES, export permits are required to trade white shark specimens internationally [94]. Such permits will not be issued without first evaluating the effect such trade may have on the species [94].

In 2007, Mexico published an Official Norm that prohibits the taking of white sharks and prohibits the landing of shark fins without the corresponding carcass [87]. In 2012, Mexico adopted a seasonal ban on fishing for all shark species in national waters in the Pacific Ocean between May and July [88]. This seasonal ban, much like the area restrictions in the US, is expected to reduce the interactions between young sharks and gillnets and thus provided the NEP white shark population increased protection [89].

\subsection{The Necessity of Endangered Species Protections}

The plethora of existing state, federal, and international regulatory mechanisms raise the question as to what, if any, additional protection threatened or endangered status would provide the NEP white shark. If the most current, foreseeable, and identifiable threat to the NEP white shark population is mortality rates cause by overutilization and overexploitation for commercial, recreational, scientific or educational purposes, then many of these regulatory mechanisms may already adequately address these threats.

Because there are already take restrictions in place for white sharks in California waters, the protection extended to the NEP white shark under the CESA would serve only to restrict incidental takings in the round haul and gillnet fisheries, which, according to some studies, have already declined significantly in the last ten years [90]. Takings for any scientific or education purposes already require a permit, and only 11 such scientific collection permits have been issued [66]. Thus, requiring a "special" incidental take permit under the CESA would not likely impact white shark populations dramatically nor aid significantly in furthering the recovery of the NEP white shark population.

Moreover, there is evidence indicating that gill net time and use restrictions may already be addressing the issues regarding protections for habitats where juveniles roam [70]. As such, adding critical habitat protections under either the ESA or CESA in order to conserve white shark nurseries would simply duplicate habitat protections that already exist.

Furthermore, the recently adopted prohibitions on attracting white sharks within the GFNMS and MBNMS provide additional protections for white sharks by reducing the frequency of interactions with humans that would otherwise result in possible disruption of natural behaviors. Finally, federal regulations regarding shark finning practices and restrictions on landing shark fins in the US EEZ offer the NEP white shark additional protections by restricting the ability to land and trade white shark fins.

In sum, state and federal protective mechanisms have been in place to help reduce negative impacts on the NEP white shark population since the 1990s. Each of the regulations specifically addresses a particular threat to the NEP white shark raised by the petitioners. As a result, protections under the CESA and ESA may not be necessary in order to adequately protect and conserve the NEP white shark.

\section{Conclusions}

Interestingly enough, and despite the many apparent threats and high shark mortality estimates, not a single shark species has been successfully listed as threatened or endangered under either the CESA or the ESA [91]. This dearth of shark listings is likely the result of the many regulations already in place that specifically address issues regarding shark conservation. This is especially true of the white shark, which enjoys several state, federal 
and international regulations specific to conserving the species.

There is some evidence indicating that the NEP white shark population has actually been increasing as a result of those regulations already in place. If true, the NEP white shark may actually represent an example of a conservation success story-a species for which endangered species protections may not be necessary in order to conserve and rebuild its population. As the IUCN has suggested, more appropriate measures for further conservation of the species would include removing the white shark from international game fish record lists and consistent, realistic treatment by the news media to counter its notoriety and inflated market value [12].

In addition to the host of regulatory mechanisms currently in place to reduce white shark mortality rates, there is also some concern amongst shark experts that protection under the CESA might actually hinder important shark research [67] [92]. Several shark scientists have voiced their opinions that listing the species under the CESA would strain the ability to conduct much-needed research that would provide more understanding of the possible threats facing sharks and their habitat [92]. According to these scientists, a CESA listing would negatively impact further research efforts by restricting their ability to obtain shark specimens or observe sharks [93]. After 1994, when California prohibited the take of white sharks, many researchers coordinated with fisherman to collect and obtain white sharks that were taken incidentally for the purposes of scientific research [93]. CESA protections would potentially prohibit incidental takings, resulting in fewer specimens accessible to researchers [92]. There are still many gaps in the scientific understanding of basic white shark biology and behavior. Thus, placing heavier burdens on white shark researchers may hinder any progress in addressing future conservation concerns.

Lastly, there are perhaps other shark species roaming US waters that might require more immediate conservation than the NEP white shark. Species such as the scalloped hammerhead and the great hammerhead are categorized as endangered on the IUCN Red List and may be more in need of additional legal attention than the white shark [94]. Resources may be better spent on species that face more immediate threats and require the extreme protective measures that the ESA, or the CESA, can offer. If the current regulatory measures are not adequately addressing the threats facing such species, then endangered species protection may afford them more appropriate levels of conservation and recovery efforts.

Like the great white shark, a species' listing denial might be cast in a negative light—a victim of bad press. It is easy to view a failure to list a species as a failure of government agencies to protect vulnerable species. The case of the NEP white shark, however, serves as an example that failure to list a species under the ESA, or the CESA, may not always constitute such a government failure. Rather than representing a lack of governmental action to protect the white shark, the NEP's denial demonstrates how forward-thinking legislation and marine life management may result in effective regulatory mechanisms that render the extreme endangered species protections unnecessary.

\section{References}

[1] Natural History Museum Ichthyology Department (2014) Shark Basics, Fla. http://www.flmnh.ufl.edu/fish/education/questions/Basics.html

[2] Shark Savers (2014) 450 Million Years of Sharks. http://www.sharksavers.org/en/education/biology/450-million-years-of-sharks1/

[3] National Geographic (2014) Marine Habitat Destruction. http://ocean.nationalgeographic.com/ocean/critical-issues-marine-habitat-destruction/

[4] Muter, B.A., et al. (2013) Australian and US News Media Portrayal of Sharks and Their Conservation. Conservation Biology, 27,187-196. http://dx.doi.org/10.1111/j.1523-1739.2012.01952.x

[5] Shark Savers (2014) Other Threats Facing Sharks. http://www.sharksavers.org/en/education/sharks-are-in-trouble/other-threats-facing-sharks/

[6] Worm, B., et al. (2013) Global Catches, Exploitation Rates, and Rebuilding Options for Sharks. Journal of Marine Policy, 40, 194-204.

[7] Inclusion of Carcharodon carcharias in Appendix II with a Zero Annual Export Quota. 13th Meeting of the Conference of the Parties, Bangkok, 2-3 October 2004, 1-40. http://www.cites.org/eng/cop/13/prop/E13-P32.pdf

[8] Compagno, L.J.V., et al. (1997) Threatened Fishes of the World: Carcharodon carcharias (Linnaeus, 1758) (Lamnidae). Environmental Biology of Fishes, 50, 61-62. http://dx.doi.org/10.1023/A:1007308406137

[9] Reid, D. and Krogh, M. (1992) Assessment of the Catches from Protective Shark Meshing off New South Wales 
Beaches between 1950 and 1990. Australian Journal of Marine and Freshwater Research, 43, 283-296. http://dx.doi.org/10.1071/MF9920283

[10] Endangered Species Act. 16 USCA §§ 1531-1544. (2012)

[11] Endangered and Threatened Wildlife; 12-Month Finding on Petitions to List the Northeastern Pacific Ocean Distinct Population Segment of White Shark as Threatened or Endangered under the Endangered Species Act, 78 Fed. Reg. 40104-126, 40126 (Jul. 3, 2013). After a 12-Month in Depth Status Review the White Shark Was Denied Listing under the ESA.

[12] Fergusson, I. (2014) Carcharodon carcharias. The IUCN Red List of Threatened Species. http://www.iucnredlist.org/details/3855/0

[13] Compagno, L.V. (2001) Sharks of the World: An Annotated and Illustrated Catalogue of Shark Species Known to Date Vol. 2 Bullhead, Mackerel and Carpet Sharks (Heterodontformes, Laniformes and Orectolobiformes), 101.

[14] MarineBio (2014) Great White Sharks, Carcharodon carcharias. http://marinebio.org/species.asp?id=38

[15] Eilperin, J. (2013) Once Bitten, Twice Shy: Our Exaggerated Fear of Shark Attacks. The Guardian. http://www.theguardian.com/science/2013/aug/06/us-shark-attack-statistics-fears

[16] Choi, C.Q. (2010) How “Jaws” Forever Changed our View of Great White Sharks. Live Science. http://www.livescience.com/8309-jaws-changed-view-great-white-sharks.html

[17] Benchley, P. (1974) Jaws; Jaws (Universal Pictures 1975).

[18] Fritcher, L. (2011) Jaws Movie: Shark Phobia for the Masses. http://phobias.about.com/od/introductiontophobias/a/jawsmovie.htm

[19] OMG Sharks (2014) Shark Movie Index. http://www.omgsharks.com/shark-movies/index.htm

[20] Eisman, A. (2003) The Media of Manipulation: Patriotism and Propaganda-Mainstream News in the United States in the Weeks Following September 11th. Critical Quarterly, 45, 55-72. http://dx.doi.org/10.1111/1467-8705.00472.

[21] Sharks and the Media. Shark Project. http://www.sharkproject.org/haiothek/index e.php?site=angst 4

[22] The Ocean Conservancy (2014) Shark Conservation. http://act.oceanconservancy.org/site/DocServer/fsSharks.pdf

[23] Brush, E. (2013) Great White Shark Controversy Exposes Illegal Government Acts \& Public Endangerment! CNN. http://ireport.cnn.com/docs/DOC-943219

[24] Chadha, A. (2014) Australian Shark Cull: Necessary Public Safety Policy or Fear Mongering? The International. http://www.theinternational.org/articles/506-australian-shark-cull-necessary-public-s

[25] Rey, N. (2014) Western Australia’s Shark Cull Will Hit Breeding Stock of Great Whites. The Guardian. http://www.theguardian.com/environment/2014/feb/23/western-australia-shark-cull-great-whites

[26] 1916-2013 United States (incl. Hawaii) Confirmed Unprovoked Attacks by White Sharks (N=106). IFMNH. http://www.flmnh.ufl.edu/fish/sharks/White/USA.htm

[27] IFMNH (2014) 1876-2013 World’s Confirmed Unprovoked Attacks by White Sharks (N=280). http://www.flmnh.ufl.edu/fish/sharks/White/World.htm

[28] IFMNH (2014) The Relative Risk of Shark Attacks to Humans. http://www.flmnh.ufl.edu/fish/sharks/attacks/relarisk.htm

[29] Dulvy, N.K., Baum, J.K., Clarke, S., Compagno, L.J.V., Cortés, E., Domingo, A., et al. (2008) You Can Swim but You Can't Hide: The Global Status and Conservation of Oceanic Pelagic Sharks and Rays. Aquatic Conservation: Marine and Freshwater Ecosystems, 18, 459-482. http://dx.doi.org/10.1002/aqc.975

[30] Andersen, J. (2014) Looming Shark Extinction. Shark Angels. http://sharkangels.org/index.php/issues-facing-sharks/looming-extinction

[31] Shark Angels (2014) Issues Facing Sharks. http://sharkangels.org/index.php/issues-facing-sharks

[32] Fairclough, C. (2014) Shark Finning: Sharks Turned Prey. Smithsonian National Museum of Natural History Ocean Portal. http://ocean.si.edu/ocean-news/shark-finning-sharks-turned-prey

[33] Cliff, G., Dudley, S.F.J. and Jury, M.R. (1996) Catches of White Sharks in KwaZulu-Natal, South Africa and Environmental Influences. In: Klimley A.P. and Ainley, D.G., Eds., Great White Sharks: The Biology of Carcharodon Carcharias, Academic Press, Waltham, 351-362. http://dx.doi.org/10.1016/B978-012415031-7/50033-1

[34] Last, P.R. and Stevens, J.D. (1994) Sharks and Rays of Australia. 2nd Edition.

[35] Heneman, B. and Glazer, M. (1996) More Rare Than Dangerous: A Case Study of White Shark Conservation in California. In: Klimley A.P. and Ainley, D.G., Eds., Great White Sharks: The Biology of Carcharodon Carcharias, Academic Press, Waltham, 481-491. http://dx.doi.org/10.1016/B978-012415031-7/50046-X

[36] Myers, R.A., Baum, J.K., Shepherd, T.D., Powers, S.P. and Peterson, C.H. (2007) Cascading Effects of the Loss of 
Apex Predatory Sharks from a Coastal Ocean. Science, 315, 1846-1850. http://dx.doi.org/10.1126/science.1138657

[37] NOAA (2012) Protecting White Sharks: Gulf of the Farallones National Marine Sanctuary Factsheet. http://farallones.noaa.gov/eco/sharks/pdf/shark_one_pager.pdf

[38] (2014) IUCN Red List Categories and Criteria: Version 3.1. http://www.iucnredlist.org/technical-documents/categories-and-criteria/2001-categories-criteria

[39] Gubili, C., Duffy, C.A.J., Cliff, G., Wintner, S.P., Shivji, M., Chapman, D., et al. (2012) Application of Molecular Genetics for Conservation of the White Shark, Carcharodon carcharias. In: Domeier, M.L., Ed., Global Perspectives on the Biology and Life History of the White Shark, CRC Press, Boca Raton, 364.

[40] Pratt, H.L. (1996) Reproduction in the Male White Shark. In: Klimley A.P. and Ainley, D.G., Eds., Great White Sharks: The Biology of Carcharodon Carcharias, Academic Press, Waltham, 131-138.

[41] Dewar, H., Eguchi, T., Hyde, J., Kinzey, D., Kohin, S., Moore, J., et al. (2013) Status Review of the Northeastern Pacific Population of White Sharks (Carcharodon carcharias) under the Endangered Species Act. NOAA.

[42] Jorgensen, S.J., Reeb, C.A., Chapple, T.K., Anderson, S., Perle, C., Van Sommeran, S.R., et al. (2010) Philopatry and Migration of Pacific White Sharks. Proceedings of the Royal Society B, 277, 679-688. http://dx.doi.org/10.1098/rspb.2009.1155

[43] Weng, K.C., O’Sullivan, J.B., Lowe, C.G., Winkler, C.E., Dewar, H. and Block, B.A. (2007) Movements, Behavior and Habitat Preferences of Juvenile White Sharks Carcharodon carcharias in the Eastern Pacific. Marine Ecology Progress Series, 338, 211-224. http://dx.doi.org/10.3354/meps338211

[44] Domeier, M.L. (2012) A New Life-History Hypothesis for White Sharks, Carcharodon carcharias, in the Northeast Pacific, in Global Perspectives on the Biology and Life History of the White Shark.

[45] NOAA (2014) Ocean Facts. http://oceanservice.noaa.gov/facts/eez.html

[46] Chapple, T.K., Jorgensen, S.J., Anderson, S.D., Kanive, P.E., Klimley, A.P., Botsford, L.W., et al. (2011) A First Estimate of White Shark, Carcharodon carcharias, Abundance off Central California. Biology Letters, 7, 581-583. http://dx.doi.org/10.1098/rsbl.2011.0124

[47] NOAA (2014) Map Showing the United States Exclusive Economic Zone. http://www.gc.noaa.gov/documents/2011/012711 gcil maritime eez map.pdf

[48] Endangered Species Act, 16 U.S.C.A. § 1533(a)(1).

[49] Endangered Species Act, 16 U.S.C.A. § 1532.

[50] (1996) Policy Regarding the Recognition of Distinct Vertebrate Population Segments under the Endangered Species Act, 61 Fed. Reg. 4722-4725, 4725.

[51] Endangered Species Act, 16 U.S.C.A. §§ 1533, 1538.

[52] Endangered Species Act, 16 U.S.C.A. §§ 1532.

[53] Cal. Code Regs. tit. 14, §670.1(i)(1)(A) (2013)

[54] Cal. Fish \& Game Code § 2062 (2013)

[55] Cal. Fish \& Game Code § 2067 (2013)

[56] California Forestry Assn. v. California Fish \& Game Commission, 156 Cal. App. 4th 1535, 1536 (Cal. App. 3d Dist. 2007)

[57] Cal. Fish \& Game Code § 2080 (2013)

[58] California Department of Fish and Wildlife (2014) State Laws, Regulations and Policy for the Incidental Take of State Listed Species under the California Endangered Species Act. http://www.dfg.ca.gov/habcon/cesa/incidental/cesa_policy_law.html

[59] Cal. Fish \& Game Code § 2052 (2013)

[60] (2012) Endangered and Threatened Wildlife; 90-Day Finding on Petitions to List the Northeastern Pacific Ocean Distinct Population Segment of Great White Shark as Threatened or Endangered Under the Endangered Species Act, 77 Fed. Reg. 59582-01.

[61] (2012) Wild Earth Guardians, Petition to List the Northeastern Pacific Ocean Distinct Population Segment of Great White Shark (Carcharodon carcharias) under the US Endangered Species Act.

[62] Endangered Species Act, 16 USC § 1533(b) (3) (A), (B).

[63] (2012) Oceana, Center for Biological Diversity and Shark Stewards, Petition to List the White Shark (Carcharodon carcharias) as Threatened or Endangered under the California Endangered Species Act. http://oceana.org/sites/default/files/reports/Oceana_NEPwhitesharkESApetition_8_10_12_final.pdf

[64] Cal. Fish \& Game Code § §2074.2(a) (2) (2013) 
[65] Cal. Code Regs. tit. 14, §670.1(d)(1) (2013)

[66] (2013) Evaluation of the Petition from Oceana, Center for Biological Diversity and Shark Stewards to List the Northeast Pacific White Shark (Carcharodon carcharias) as Threatened or Endangered, Report to the Fish and Game Commission 36. https://nrm.dfg.ca.gov/FileHandler.ashx?DocumentID=58548\&inline=1

[67] Domeier, M.L. (2014) How Many White Sharks Are Swimming in the North Eastern Pacific? Marine CSI. http://www.marinecsi.org/news-events/\#sthash.6wtbuwl3.dpuf

[68] Evaluation of the Petition from Oceana, Center for Biological Diversity and Shark Stewards to List the Northeast Pacific White Shark (Carcharodon carcharias) as Threatened or Endangered, Report to the Fish and Game Commission 35. Incidental Reported Catch Rates of YOY and Juvenile White Sharks Has Increased in Southern California since the 1994 Gill Net Ban.

[69] Cal. Fish \& Game Code §§ 5517, 8599 (2013)

[70] Lowe, C., Blasius, M.E., Jarvis, E.T., Mason, T.J., Goodmanlowe, G.D. and O’Sullivan, J.B. (2012) Historic Fishery Interactions with White Sharks in the Southern California Blight. In: Domeier, M.L., Ed., Global Perspectives on the Biology and Life History of the White Shark, CRC Press, Boca Raton,169-185.

[71] Pondella, D.J. and Allen, L.G. (2008) The Decline and Recovery of Four Predatory Fishes from the Southern California Bight. Marine Biology, 154, 307-313. http://dx.doi.org/10.1007/s00227-008-0924-0

[72] (2011) Magnuson-Stevens Act, Shark Finning, 50 C.F.R. § 600.1200; Pacific Fishery Management Council [PFMC], Fishery Management Plane for US West Coast Fisheries for Highly Migratory Species. http://www.westcoast.fisheries.noaa.gov/fisheries/migratory_species/highly_migratory_species.html

[73] 50 C.F.R. § 600.1200.

[74] Endangered Species Act, 16 U.S.C.A. \$1857(1)(P).

[75] National Oceanic and Atmospheric Administration (2014) 15 C.F.R. § 922.1; Protecting White Sharks. http://farallones.noaa.gov/eco/sharks/pdf/shark one pager.pdf

[76] Endangered Species Act, 16 U.S.C.A. §§ 1801-1884.

[77] Pacific Fishery Management Council (2014) Who We Are and What We Do. http://www.pcouncil.org

[78] Pacific Fishery Management Council (2014) Highly Migratory Species: Background. http://www.pcouncil.org/highly-migratory-species/background/

[79] Endangered Species Act, 16 U.S.C.A. §1857(1)(P).

[80] NOAA Fisheries (2014) Swordfish Large Mesh Drift Gillnet. Taking of Marine Mammals Incidental to Commercial Fishing Operations; Pacific Offshore Cetacean Take Reduction Plan Regulations, 62 Fed. Reg. 51805-01 (October 3, 1997). http://www.westcoast.fisheries.noaa.gov/fisheries/migratory species/hms DGN gear.html

[81] (2014) Species, Convention on the Conservation of Migratory Species of Wild Animals. http://www.cms.int/en/species

[82] FAO Fisheries and Aquaculture Department (2014) International Plan of Action for the Conservation and Management of Sharks. http://www.fao.org/fishery/ipoa-sharks/en

[83] International Efforts to Advance the Goals of the Shark Finning Prohibition Act 35-34. http://www.nmfs.noaa.gov/stories/2012/08/docs/rfmo_sharks_international_efforts.pdf

[84] (2014) Introduction, Memorandum of Understanding on the Conservation of Migratory Sharks. http://sharksmou.org/introduction

[85] (2014) List of Signatories, Memorandum of Understanding on the Conservation of Migratory Sharks. http://sharksmou.org/list-of-signatories

[86] (2014) The CITES Appendices. http://www.cites.org/eng/app/index.php

[87] Norma Official Mexicana NOM-029-PESC-2006, Pesca Responsable de Tiburones y Rayas. Especificaciones para Su Aprovechamieto. http://www.profepa.gob.mx/innovaportal/file/3438/1/nom-029-pesc-2006.pdf

[88] Shark Savers (2014) Laws Protecting Sharks. http://www.sharksavers.org/en/our-programs/shark-sanctuaries/learn-more/laws-protecting-sharks/

[89] Santana-Morales, O., et al. (2012) Incidental Catch and Ecological Observations of Juvenile White Sharks, Carcharodon carcharias, in Western Baja California, Mexico, Conservation Implications. In: Domeier, L., Ed., Global Perspectives on the Biology and Life History of the White Shark, CRC Press, Boca Raton, 187-198.

[90] California Department of Fish and Wildlife (2014) Status of the Fisheries Report 2011: White Shark. https://nrm.dfg.ca.gov/FileHandler.ashx?DocumentID=65496\&inline=true

[91] NOAA Fisheries (2014) Threatened and Endangered Species, California Department of Fish and Wildlife. Endangered and Threatened Marine Species. https://www.dfg.ca.gov/wildlife/nongame/t_e_spp/ 
http://www.nmfs.noaa.gov/pr/pdfs/species/esa_table.pdf

[92] Southern Fried Science (2013) Why a California Great White Shark Scientist Opposes CA Endangered Species Act Protections. http://www.southernfriedscience.com/?p=14424

[93] Servick, K. (2013) Permit System Puts Tougher Regulation on Fishermen, Scientists Who Catch Great White Shark. http://www.santacruzsentinel.com/ci_22716932/permit-system-puts-tougher-regulation-fishermen-scientists-who

[94] Baum, J. (2014) Sphyrna lewini. IUCN Red List of Threatened Species. http://www.iucnredlist.org/details/39385/0 
Scientific Research Publishing (SCIRP) is one of the largest Open Access journal publishers. It is currently publishing more than 200 open access, online, peer-reviewed journals covering a wide range of academic disciplines. SCIRP serves the worldwide academic communities and contributes to the progress and application of science with its publication.

Other selected journals from SCIRP are listed as below. Submit your manuscript to us via either submit@scirp.org or Online Submission Portal.
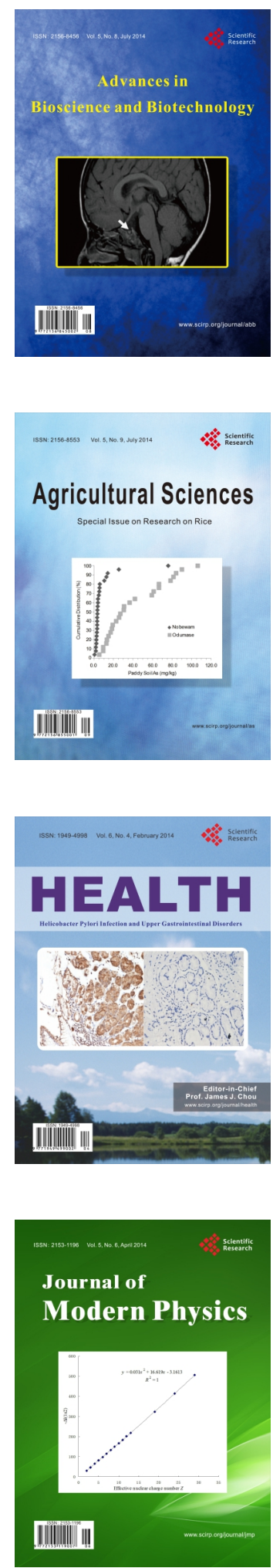
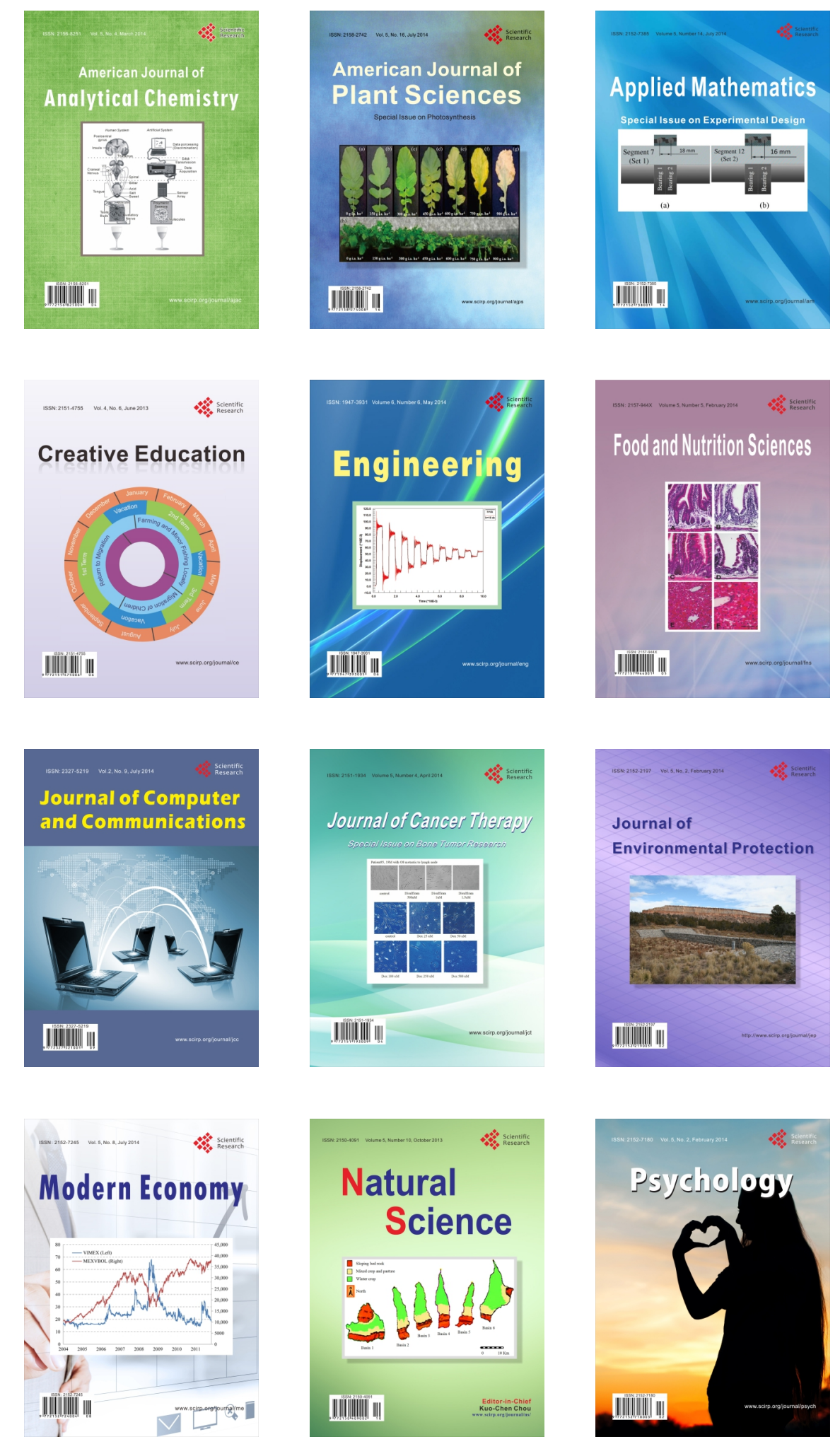